\title{
MORE ON THEORETICAL MORPHOSPACE AND ITS RELATION TO FRESHWATER GOMPHONEMOID-CYMBELLOID DIATOM (BACILLARIOPHYTA) LINEAGES
}

\author{
JANICE L. PAPPAS \\ Museum of Paleontology, University of Michigan \\ 1109 Geddes Ave., Ann Arbor, MI 48109-1079, USA \\ jlpappas@umich.edu
}

Received 26 June 2007

Revised 22 August 2007

\begin{abstract}
All forms from hypothesized gomphonemoid-cymbelloid lineages were constructed using three-dimensional (3D) parametric equations with the same boundary intervals for all forms. To construct a theoretical morphospace, the absolute value of the Riemann sum of differences between pairs of forms in terms of surfaces in the $x$-, $y$ - and $z$-directions was determined and plotted in $3 \mathrm{D}$ space. In general, naviculoid forms occupied the lowest valued morphospace, and cymbelloid and gomphonemoid forms occupied different higher valued morphospaces. In particular, Anomoeoneis, Brebissonia and Placoneis were basal to cymbelloid and gomphonemoid forms. Brebissonia was found to be more closely related to gomphonemoid forms, and Placoneis was found to be more closely related to cymbelloid forms. Reimeria was found to be in lower valued morphospace than other cymbelloid forms, including Encyonema. Didymosphenia was found to be more closely associated with cymbelloid morphospace. Gomphocymbelloid forms were more closely associated with gomphonemoid forms. These results are complementary to the previous study and mostly supported Kociolek and Stoermer's cladistic analysis of gomphonemoid-cymbelloid lineages. In addition, some ideas concerning evolutionary pathways and ontogeny with respect to theoretical morphospaces were explored.
\end{abstract}

Keywords: Diatoms; Cymbelloid; Gomphonemoid; Naviculoid; Parametric Equations; Quadratic Surfaces; Theoretical Morphology.

\section{Introduction}

Cladistic analysis and phylogenetic trees are depictions of the degree of closeness in relationship among a group of taxa. Often, phylogenies are based on morphological characters that a group of taxa share to some degree. The relationship between morphology and phylogeny is important in inferring evolutionary pathways for a group of closely related taxa.

Theoretical morphology has been used to encompass all the possible ways in which form actually varies within a group of taxonomically identifiable organisms. ${ }^{1}$ Unlike empirical morphology, theoretical morphology seeks to produce a picture of information that is biologically relevant to a group of taxa, especially when such 
information is not available by other means. Moreover, empirical morphology is a subset of theoretical morphology providing a snapshot of taxa at a given time, whereas theoretical morphology is a generalization and extension of possible empirical morphologies. Recent studies using theoretical morphological concepts include those on foraminiferal shells illustrating morphospace transitions and morphotrees, ${ }^{2}$ helical colonial bryozoans and algorithmically defined forms ${ }^{3}$ and the role of adaptive landscapes in understanding evolution. ${ }^{4}$ Such studies are important for their contribution to understanding the connection between morphology and other biological evidentiary considerations such as phylogenetic and evolution studies.

The geometry of morphology has become increasingly recognized in diatom biology ${ }^{5,6}$ and was used in a previous study of gomphonemoid and cymbelloid forms,$^{7}$ one of the most studied groups of diatoms. ${ }^{8-14}$ In the previous study, ${ }^{7}$ while support was found geometrically for a number of claims in Kociolek and Stoermer's ${ }^{11,13}$ hypotheses, other claims were untested at that time. The relation between the geometry of diatom form and phylogeny can be further tested using specific forms created from three-dimensional (3D) parametric equations and combining these results in a theoretical morphospace.

Within a class of 3D geometric objects, such as spheroids, ellipsoids and cylinders, shape can be used as a gauge of variation with respect to relative proportions of a given form. ${ }^{15}$ As with all diatoms, naviculoid, gomphonemoid and cymbelloid forms are essentially modifications of a flattened cylinder where amorphous silica is deposited in a wide variety of shapes and patterns. ${ }^{16-19}$ That is, by distorting a flattened cylinder in the apical, transapical and pervalvar planes, naviculoid, gomphonemoid and cymbelloid forms can be constructed. Moreover, in the transapical plane, the difference between gomphonemoid and cymbelloid forms is evident because of symmetry. The difference in $x-y$ surfaces between gomphonemoid and cymbelloid forms defines their geometric differences as well. Parametric equations used to create naviculoid, gomphonemoid and cymbelloid forms are based on quadratic surfaces, and these equations serve as instructions for the outline of the forms as well as the surfaces.

How do geometric differences between forms, as the differences in surfaces in the apical, transapical and pervalvar planes, relate to the results of phylogeneticallyrelated taxa in a cladistic analysis ${ }^{11}$ based on actual morphological characters? That is, what is the relationship between inferred phylogeny and differences between surfaces of particular related forms? As in the previous study, the difference in surfaces in each of the $x$-, $y$ - and $z$-directions is measured as the absolute value of the Riemann sum of differences. ${ }^{7}$ For each pair of differences in each direction, similarity in surfaces is given by values close to zero, and dissimilarity in form is given by the highest value per direction. ${ }^{7}$ Phylogeny can be viewed with respect to the combined occupied morphospace of all pairs of forms compared, and the relationship among particular theoretical forms might be used as a gross indicator of approximate order of related taxa. 
In the previous study, we were concerned about the order of the relations among naviculoid, gomphonemoid and cymbelloid forms. ${ }^{7}$ We were also concerned about particular forms, namely Brebissonia, Encyonema, Gomphoneis, and gomphocymbelloid forms. In the current study, not only are we interested in these forms, but more importantly, we are interested in the naviculoid forms of Anomoeoneis and Placoneis as well as the cymbelloid form of Reimeria and the form for Didymosphenia, and where these forms are positioned with respect to gomphonemoid-cymbelloid phylogeny. In this way, we want to cover all the possible forms for the phylogenetic hypotheses put forth by Kociolek and Stoermer ${ }^{11,13}$ and test our results with respect to their hypotheses. In addition, we are interested in determining what the geometric connection is between order of taxa in a hypothesized phylogeny and the difference in surfaces among theoretical naviculoid, gomphonemoid and cymbelloid forms. Finally, we are interested in determining what, if any, relevance theoretical morphospaces and morphologies have with regard to evolutionary pathways, ontogeny, and whether the methods of this study can be used for evaluating cladistic analysis of other groups of closely related diatoms.

\section{Methods}

\subsection{Conceptual background for using $3 D$ parametric equations for theoretical morphologies}

For each form, parametric equations in three dimensions are parametric surfaces that are also quadratic surfaces. ${ }^{7}$ A function serves as the definition for each variable in $x, y$ and $z$ in the $x-y, y-z$ and $z-x$ planes. In each plane, the figure is mapped to a space, and parameters $t, u$ are independent and defined as

$$
(t, u) \rightarrow[f(t, u), g(t, u), h(t, u)]
$$

where

$$
\begin{aligned}
& f(t, u)=x \\
& g(t, u)=y \\
& h(t, u)=z
\end{aligned}
$$

and a parametric surface, $S$, is defined as

$$
S(t, u)=[f(t, u), g(t, u), h(t, u)] .
$$

The parameters, $t, u$, represent gross surface pattern in that $t$-rulings represent diatom valve striae and $u$-ruling represents the raphe/sternum area. In this way, morphology of valve shape and pattern are represented by $3 \mathrm{D}$ parametric equations. In order to retain shape and pattern, restrictions are necessary on the allowable functions, boundary conditions, and range of values of coefficients in each function. 


\subsection{Refinement of the 3D parametric equation framework for use in creating theoretical morphospace}

Naviculoid forms were used as the basis of the theoretical morphospace. In this study, the differences between forms were minimized with respect to each variable for all forms. That is, the same basic equation was used in the $x$-, $y$ - and $z$-directions with as little modification as possible to illicit a change between forms. The changes that were made in $x$ -,$y$ - and $z$-variables were incremental in function and magnitude of coefficients. The result was that the majority of gomphonemoid and cymbelloid forms were as similar as possible in function with naviculoid forms, only requiring the most change functionally in the $y$-direction. Differences approaching zero result when the same function is used for each variable among all forms. There is the narrowest range of possibilities that are allowable to generate forms for theoretical morphospace.

In addition, two specific modifications were made that were different from the previous study. ${ }^{7}$ The first modification involved the $z$-function in sets of parametric equations, and the second modification involved the value of the differential, $d u$. These modifications were necessary not only to encompass all the particular forms created, but also to retain minimization of the difference per variable among all forms. That is, the differences in the $x-, y$ - and $z$-directions are restricted to be as small as possible using the same boundary conditions for all forms. When compared to the previous study, ${ }^{7}$ the minimization of differences in the current study is a way of fine-tuning and further constraining the 3D parametric equations. With the multitude of possibilities for diatom shape and pattern, small numerical or functional changes can produce large morphological changes from form to form.

The modified generalized set of 3D parametric equations are:

$$
\begin{aligned}
& x=k \sin \left(\frac{t}{2}\right)+[\text { function }] \\
& y=n \operatorname{sech}(m t) \tanh (10 u)+[\text { function }] \\
& z=\cos (q t)[\text { function }]
\end{aligned}
$$

where $3 \leq k \leq 8,0<m, n<1.5$ with $m \neq n, 0<q \leq 1$, and [function] is one or more circular or hyperbolic functions, involving only the sine, cosine, hyperbolic secant, and/or hyperbolic tangent. The fewest combinations of circular and hyperbolic functions is added to the base scheme to accommodate particular forms in the $x-y, y-z$ or $z-x$ planes. The boundary conditions and differentials used are:

$$
t=(-\pi, \pi), \quad d t=\frac{\pi}{16}
$$

and

$$
u=(-2 \pi, 2 \pi), \quad d u=\pi .
$$


As in the previous study, comparisons between forms from variable to variable were calculated as the absolute value of the area between curves as the Riemann sum of differences defined as the generalized definite integral: ${ }^{7}$

$$
A=\mid \int_{t, u} \boldsymbol{v a r}_{i}-\boldsymbol{v a r}_{j}[\text { differential }] \mid
$$

or

$$
A_{x, y, \text { orz }}=\left|\int_{t} \int_{u} \boldsymbol{v a r}_{\begin{array}{c}
x_{i} \\
y_{i} \\
z_{i}
\end{array}}-\boldsymbol{v a r}_{\substack{x_{j} \\
y_{j} \\
z_{j}}} d u d t\right|
$$

where area is $A$, and $v a r_{i}$ and $v a r_{j}$ represent the same variable of functions for the $i$ th and $j$ th forms, using parameters $t$ and $u$ as specified above. After iterative integration for pairwise evaluation, a numerical triplet for each comparison resulted. The numerical triplets represent sum of differences in surfaces as the extent of the differences between forms in the $x$-, $y$ - and $z$-directions.

All coordinate triplets as a matrix were plotted as the sum of the differences in surfaces for $x$-, $y$-, and $z$-directions in a $3 \mathrm{D}$ plot. The triplets were plotted from lowest to highest value, guided by the lowest differences in surfaces in the $x$-direction, then within a contiguous space of paired differences, the lowest differences in the $y$-, and subsequently, z-directions was used. As in the previous study, the total space occupied represents the subset of the total possible morphospace for the forms analyzed. ${ }^{7}$

Some of the forms used in this study were reconstructed using Persistence of Vision Ray Tracer (POV-Ray Tracer) $3.6^{20}$ software. A composite of the reconstructed forms includes some naviculoid, cymbelloid and gomphonemoid forms as well as Didymosphenia that were not part of the previous study. For more details on all the methods used in this study, see Pappas. ${ }^{5,7}$

\section{Results}

Using the generalized set of 3D parametric equations specified, 32 forms were created, including three naviculoid, ten cymbelloid, 11 gomphonemoid, five gomphocymbelloid, and two Reimeria forms as well as one Didymosphenia form. Specifically, of all the forms, one each of naviculoid forms Anomoeoneis, Placoneis, and Brebissonia were created, as were one form each for Encyonema of the cymbelloid forms and Gomphoneis of the gomphonemoid forms. A total of 106 comparisons were made.

Specifications for functions used and the range of values for coefficients for each category of forms is given in Table 1. The new forms used in this study required the most modification functionally in order to fit the more constrained generalized 3D parametric equation scheme. Equations and examples of a Brebissonia form, cymbelloid and gomphonemoid forms can be found in Pappas. ${ }^{7}$ In this study, the new naviculoid forms included Anomoeoneis (Fig. 1) and Placoneis (Fig. 2). 
Table 1. 3D parametric equations for variables $x, y$, and $z$ used for groups of theoretical forms and complete list of coefficient values.

\begin{tabular}{|c|c|c|c|}
\hline Form & $X$ & $Y$ & $Z$ \\
\hline $\begin{array}{l}\text { Anomoeoneis } \\
\text { Placoneis }\end{array}$ & $k \sin \left(\frac{t}{2}\right)$ & $\begin{array}{l}n \operatorname{sech}(m t) \tanh (10 u) \\
\quad+j \cos (3.8 t+3) l \tanh (u)\end{array}$ & $\cos \left(\frac{t}{8}\right)$ \\
\hline Brebissonia & $k \sin \left(\frac{t}{2}\right)$ & $n \operatorname{sech}(m t) \tanh (10 u)$ & $\cos \left(\frac{t}{8}\right)$ \\
\hline $\begin{array}{l}\text { Cymbelloid } \\
\text { Encyonema }\end{array}$ & $k \sin \left(\frac{t}{2}\right)$ & $\begin{array}{l}n \operatorname{sech}(m t) \tanh (10 u) \\
\quad+r \operatorname{sech}(s t)\end{array}$ & $\cos \left(\frac{t}{8}\right)$ \\
\hline $\begin{array}{l}\text { Reimeria } \\
\text { Gomphocymbella }\end{array}$ & $\begin{array}{l}k \sin \left(\frac{t}{2}\right) \\
\quad+c \operatorname{sech}(t)\end{array}$ & $\begin{array}{l}n \operatorname{sech}(m t) \tanh (10 u) \\
\quad+j \cos (5 t) l \tanh (u) \\
\quad+w \operatorname{sech}(t)\end{array}$ & $\cos \left(\frac{t}{8}\right)$ \\
\hline $\begin{array}{l}\text { Gomphonemoid } \\
\text { Gomphoneis }\end{array}$ & $\begin{array}{l}k \sin \left(\frac{t}{2}\right) \\
\quad-\operatorname{sech}\left(v t^{p}\right)\end{array}$ & $n \operatorname{sech}(m t) \tanh (10 u)$ & $\cos \left(\frac{t}{8}\right)$ \\
\hline Didymosphenia & $\begin{array}{l}k \sin \left(\frac{t}{2}\right) \\
-\cos (q t)\end{array}$ & $n \operatorname{sech}(m t) \tanh (10 u)$ & $\begin{array}{l}\cos \left(\frac{t}{4}\right) \tanh (u) \\
\quad+\sin (3 t+3) \tanh (u)\end{array}$ \\
\hline
\end{tabular}

$c=\left\{\begin{array}{ll}0 & \text { for Reimeria } \\ 1 & \text { for Gomphocymbella }\end{array}\right\}$

$0.5 \leq k \leq 8$

$0<j, l, w<0.5, j \neq l \neq w$

$0<m, n, r, s, v<2, m \neq n \neq r \neq s \neq v$

$p=1,2$

$0<q \leq 1$

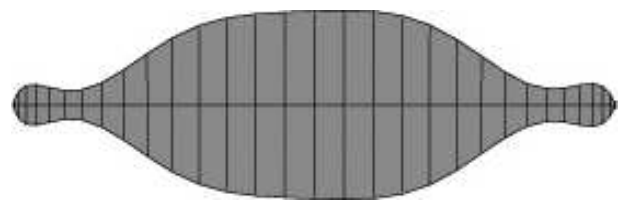

Fig. 1. Anomoeoneis form.

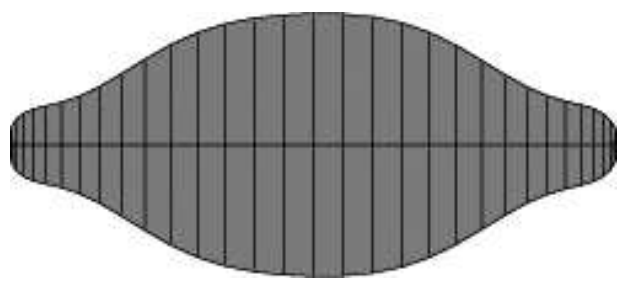

Fig. 2. Placoneis form.

They are represented by the parametric equations:

$$
\begin{aligned}
& x=5 \sin \left(\frac{t}{2}\right) \\
& y=1.9 \operatorname{sech}(1.2 t) \tanh (10 u)+0.9 \cos (3.8 t+3) 0.2 \tanh (u) \\
& z=\cos \left(\frac{t}{8}\right)
\end{aligned}
$$


and

$$
\begin{aligned}
& x=8 \sin \left(\frac{t}{2}\right) \\
& y=4 \operatorname{sech}(0.9 t) \tanh (10 u)+1.4 \cos (3.8 t+3) 0.1 \tanh (u) \\
& z=\cos \left(\frac{t}{8}\right),
\end{aligned}
$$

respectively.

For Reimeria (Fig. 3), parametric equations for a representative form were:

$$
\begin{aligned}
& x=4 \sin \left(\frac{t}{2}\right) \\
& y=\operatorname{sech}(0.6 t) \tanh (10 u)+0.7 \cos (5 t) 0.07 \tanh (u)+0.2 \operatorname{sech}(t) \\
& z=\cos \left(\frac{t}{8}\right) .
\end{aligned}
$$

The form generated for Didymosphenia (Fig. 4) was based on the parametric equations of:

$$
\begin{aligned}
& x=6 \sin \left(\frac{t}{2}\right)+\cos (t) \\
& y=\operatorname{sech}(1.2 t) \tanh (10 u) \\
& z=\cos \left(\frac{t}{4}\right) \tanh (u)+\sin (3 t+3) \tanh (u) .
\end{aligned}
$$

Area between curves for each variable was calculated as the absolute value of the Riemann sum of differences, combined in a matrix, and plotted as the total 3D theoretical morphospace for gomphonemoid-cymbelloid forms (Fig. 5). As in the previous study, ${ }^{7}$ most of the combined morphospace is broadest at the bottom of the plot where forms are most similar. Movement away from the origin and base of the plot depicts areas where forms differentiate from each other.

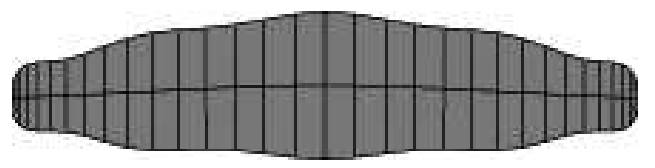

Fig. 3. Reimeria form.

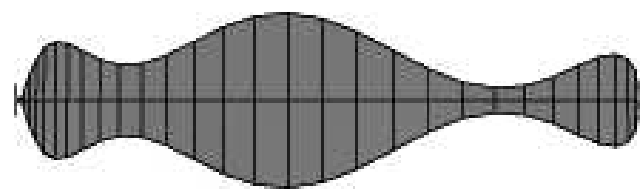

Fig. 4. Didymosphenia form. 


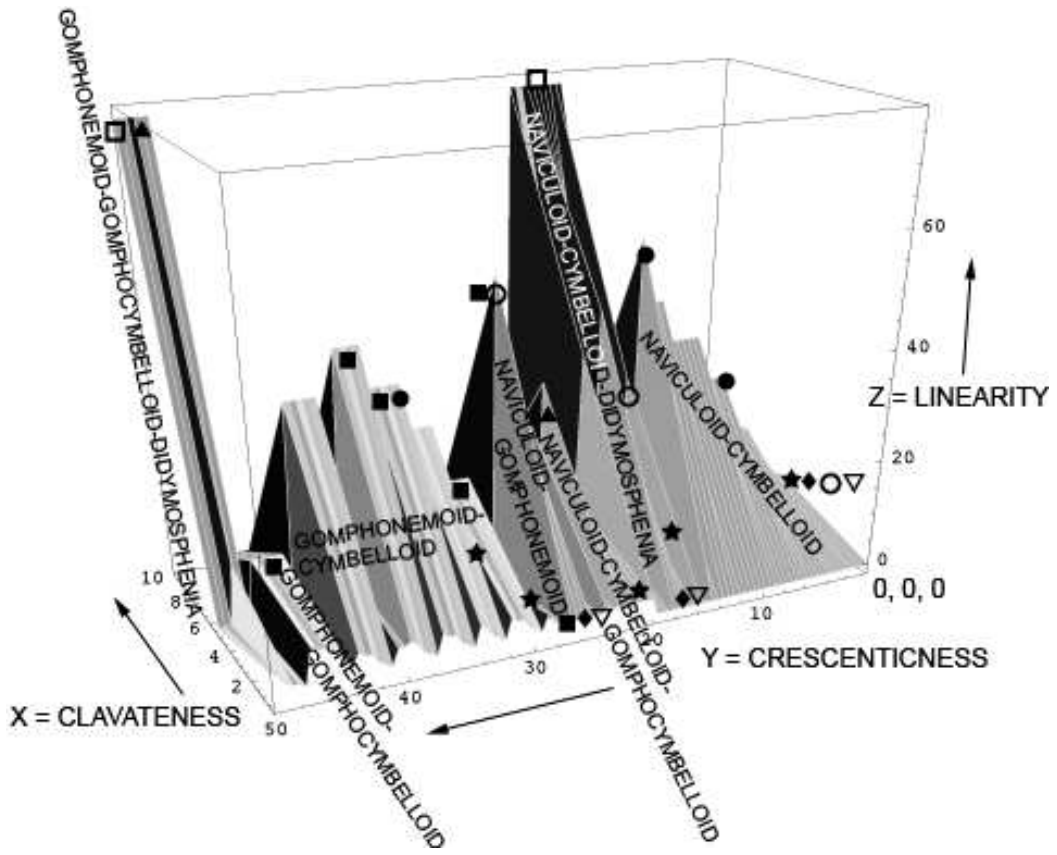

Fig. 5. Pairwise comparison of forms plotted as coordinate triplets from the absolute value of the Riemann sum of differences between variables. Combinations of forms are labeled. Particular taxon forms are labeled as: $\nabla=$ Anomoeoneis, $\diamond=$ Brebissonia, $\square=$ Didymosphenia, $\boldsymbol{\bullet}=$ Encyonema, $\boldsymbol{\Delta}=$ Gomphocymbella, $\mathbf{\square}=$ Gomphoneis, $\bigcirc=$ Placoneis, $\star=$ Reimeria .

From pairwise comparisons, individually named taxon forms were indicated in sections of morphospace based on coordinate triplet values whereby maximum difference in the $x$-, $y$ - and/or $z$-directions occur (Fig. 5). These pairwise comparisons are partially ordered in the $x$-, $y$ - and/or $z$-directions as well. Individually named taxon forms appear multiple times within theoretical morphospace since they reflect their pairwise comparison with cymbelloid and gomphonemoid forms. Using this, individual taxa can be ordered within that morphospace when all coordinate triplets are compared. That is, the individual forms for Anomoeoneis, Placoneis, Brebissonia, Encyonema, Gomphoneis, and Didymosphenia will be partially ordered in $x-, y$ - and/or $z$-directions within a given section of theoretical morphospace and are plotted accordingly.

Specifically, Anomoeoneis, Placoneis and Brebissonia will be partially ordered in naviculoid-cymbelloid, naviculoid-gomphonemoid, naviculoid-cymbelloid-Didymosphenia, and naviculoid-cymbelloid-gomphocymbelloid sections of morphospace. Encyonema will be partially ordered in naviculoid-cymbelloid, naviculoidcymbelloid-Didymosphenia, and naviculoid-cymbelloid-gomphocymbelloid sections of morphospace. Didymosphenia will be partially ordered within naviculoid-cymbelloid-Didymosphenia and gomphonemoid-gomphocymbelloidDidymosphenia sections of morphospaces. Gomphoneis will be partially ordered 
within naviculoid-gomphonemoid, gomphonemoid-cymbelloid, and gomphonemoidgomphocymbelloid sections of morphospace (Fig. 5).

The coordinate triplet values for the two Reimeria forms differed in the $y$-direction with respect to all other forms and were indicated as such within a section of morphospace when numerically separable. For Reimeria, coordinate triplets from pairwise comparisons yielded different values in the $x$-direction for gomphonemoid-containing morphospace and the same values in the $x$-direction for naviculoid- and cymbelloid-containing morphospace. In the $y$-direction, Reimeria exhibited more variability with respect to naviculoid- and cymbelloidcontaining morphospace in contrast to that for gomphonemoid-containing morphospace where values were in a narrow range. This is a partial ordering reflected in naviculoid-cymbelloid, naviculoid-cymbelloid-Didymosphenia, naviculoid-cymbelloid-gomphocymbelloid, and gomphonemoid-cymbelloid sections of morphospace (Fig. 5).

The coordinate triplet values for the five gomphocymbelloid forms yielded the same result in pairwise comparisons with all other forms and was treated as a single taxon form. For gomphocymbelloid forms, pairwise comparison values were the same in the $x$-direction and varied in the $y$-direction within cymbelloidcontaining morphospace, while varying in the $x$-direction and remaining the same in the $y$-direction within gomphonemoid-containing morphospace. This partial ordering is reflected in naviculoid-cymbelloid-gomphocymbelloid, gomphonemoidgomphocymbelloid, and gomphonemoid-gomphocymbelloid-Didymosphenia sections of morphospace (Fig. 5).

Overall, naviculoid forms occupy approximately the first half of the plot, cymbelloid forms occupy at least three-fourths of the plot, and gomphonemoid forms occupy the last two-thirds of the plot (Fig. 5). Didymosphenia occupies two different sections of the plot, being farthest away from the origin with respect to gomphonemoid forms, but closer to the origin with respect to cymbelloid forms (Fig. 5).

Generally, the naviculoid forms of Anomoeoneis, Brebissonia and Placoneis are basal to cymbelloid and gomphonemoid forms. The only exception to this is Placoneis, occurring in higher valued morphospace than Anomoeoneis and Brebissonia with respect to Didymosphenia and gomphonemoid forms (Fig. 5).

The naviculoid forms occur in lower valued morphospace in contrast to all other cymbelloid forms, and in particular, they occur in lower valued morphospace with respect to Reimeria and Encyonema. In the naviculoid-cymbelloid, gomphonemoidcymbelloid, and naviculoid-cymbelloid-Didymosphenia sections of morphospace, Reimeria occupies lower valued morphospace than Encyonema. In pairwise comparisons, values for the two Reimeria forms were the same in the $x$ - and $z$-directions, with the only difference between these forms being in the $y$-direction. The difference was small so that Reimeria was still found to be more basal and in lower valued morphospace than Encyonema. 


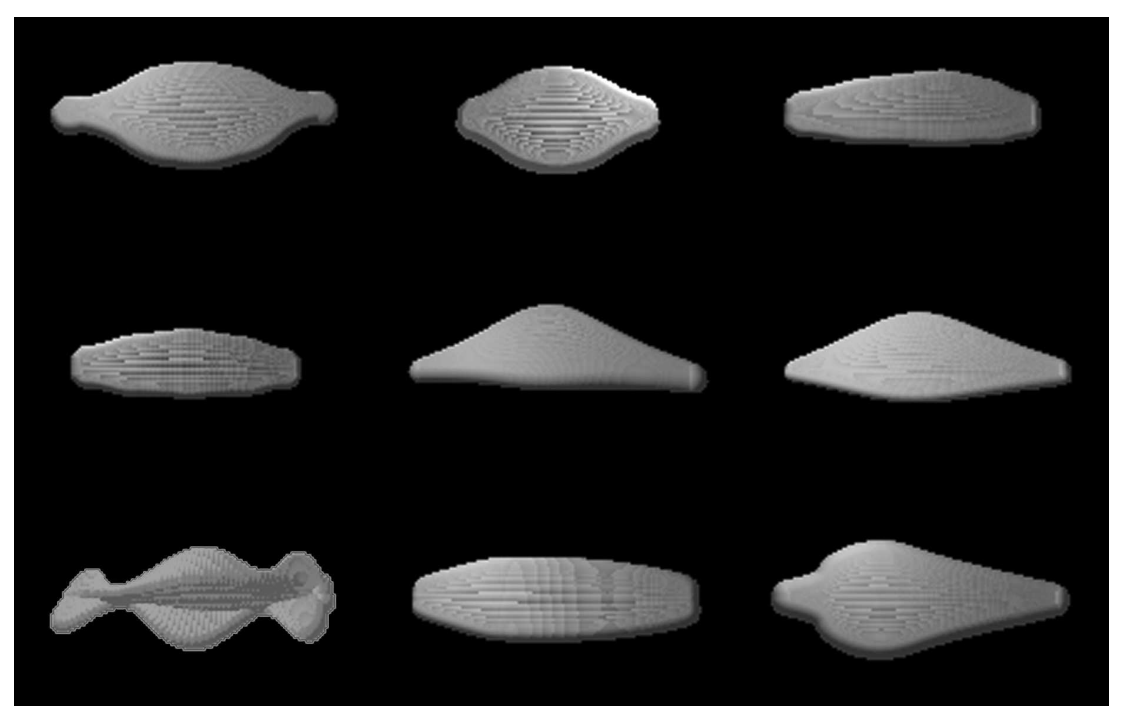

Fig. 6. A composite of nine diatom forms generated using POV-Ray Tracer 3.6 software. First row (top): Anomoeoneis, Placoneis, Gomphocymbella. Second row (middle): Reimeria, Encyonema, a cymbelloid form. Third row (bottom): Didymosphenia, Gomphoneis, a gomphonemoid form.

In the gomphonemoid sections of the total morphospace, Gomphoneis occupies low and high valued morphospace, so it is not clear what the relationship is between this particular form and other gomphonemoid forms (Fig. 5). Gomphocymbelloid forms occupy high valued morphospace with respect to naviculoid-cymbelloid forms and Didymosphenia, and low valued morphospace with respect to gomphonemoid forms (Fig. 5). Didymosphenia occupied the highest valued morphospace of all forms, but was in lower valued morphospace with cymbelloid forms in contrast to gomphonemoid forms (Fig. 5).

A composite of some of the forms used in this study were generated using Persistence of Vision Ray Tracing (POV-Raytracing 3.6) ${ }^{20}$ software. The reconstructions are illustrated in Fig. 6.

\section{Discussion}

Although the 3D parametric equations used are invariant, all the restrictions placed upon them constrain what forms are graphically possible. The $3 \mathrm{D}$ parametric equations can be converted into other circular and hyperbolic functions or expressed in exponentials or natural logarithmic functions. However, the properties of functions other than circular and hyperbolic functions are not useful with respect to the depiction of the results graphically. Combinations of other circular and hyperbolic functions may produce similar outcomes to those achieved, but it is unclear if such new combinations could do so under similar restrictions so that minimization of differences between all forms occurs. 
The constrained sets of 3D parametric equations are used to model all the possible gomphonemoid and cymbelloid taxa that are phylogenetically related. With a minimization of differences among forms, such forms are morphologically and geometrically meaningful relative to one another. Pairwise comparison of forms ensures that all forms are connected to each other within theoretical morphospace.

Small functional or numerical changes from one form to another with respect to $3 \mathrm{D}$ parametric equations produce large changes graphically. These graphical changes reflect large changes in shape among morphological forms on a generic level as in naviculoid forms of Anomoeoneis, Placoneis and Brebissonia and cymbelloid (including Reimeria and Encyonema) and gomphonemoid (including Gomphoneis) forms as well as gomphocymbelloid forms and Didymosphenia. That small functional or numerical changes can produce large differences in diatom form has been illustrated elsewhere. ${ }^{5-7}$

As in the previous study, ${ }^{7}$ results from the current study indicated that naviculoid forms were basal to cymbelloid and gomphonemoid forms, and they occupied the lowest valued morphospace. Cymbelloid and gomphonemoid forms occupied different regions of morphospace, coinciding with the previous study ${ }^{7}$ and supporting Kociolek and Stoermer's ${ }^{11,13}$ cladistic analysis.

In general, the results of this study complement the previous study. ${ }^{7}$ However, there were some differences in position of pairwise comparisons among gomphonemoid and cymbelloid forms. In spite of the results of the current study, some of the same unresolved issues with phylogenetic position remain.

In Kociolek and Stoermer's ${ }^{11}$ cladistic analysis of cymbelloid and gomphonemoid taxa, Anomoeoneis and Placoneis were ancestral to all forms. In theoretical morphospace, Anomoeoneis occupied some of the lowest valued morphospace as did Brebissonia and Reimeria. Placoneis occupied somewhat lower valued morphospace with respect to cymbelloid forms and higher valued morphospace with respect to gomphonemoid forms (Fig. 5). A phylogenetic tree based on molecular data depicted Placoneis spp. to be more closely related to Encyonema cf. sinicum than Gomphonema capitatum. ${ }^{21}$ However, a combination of morphological, cytological and reproductive data was used to produce a phylogenetic tree that depicted Placoneis gastrum to be more closely related to Gomphonema parvulum than to Encyonema prostratum or Cymbella spp. ${ }^{21}$ The gradation of position of Placoneis in theoretical morphospace may reflect this ambiguity, but the actual phylogenetic position is still unclear.

In the same phylogenetic tree of combined data, Anomoeoneis sphaerophora was not depicted as closely related to Placoneis, gomphonemoid or cymbelloid taxa. ${ }^{21}$ In another classification scheme, Anomoeoneis was thought to be most closely related to Placoneis, Gomphonema and Cymbella, despite having a very different valve shape. ${ }^{22}$ If theoretical morphological analysis is correct, then Anomoeoneis, like Brebissonia is more closely related to gomphonemoid forms (Fig. 5). However, Kociolek and Stoermer's ${ }^{11,13}$ cladistic analysis does not indicate that this is the case for 
Anomoeoneis since the taxon was used as an outgroup. The phylogenetic position of Anomoeoneis has not been resolved to date. ${ }^{21}$

To reiterate, Brebissonia occupied low valued morphospace as it did in the previous study. ${ }^{7}$ Moreover, Brebissonia occupied lower valued morphospace with gomphonemoid forms than it did with cymbelloid forms (Fig. 5). That is, Brebissonia is ancestral to gomphomemoid forms but not to cymbelloid forms. A similar result as was found in the previous study, ${ }^{7}$ and this supports Kociolek and Stoermer's ${ }^{11,13}$ hypotheses about the phylogenetic position of Brebissonia.

In theoretical morphospaces including cymbelloid forms, Reimeria occupied lower valued morphospace when compared to cymbelloid forms, including Encyonema. This finding indicates that Reimeria is more primitive than Encyonema. Moreover, Reimeria is more closely aligned with cymbelloid forms, and not gomphonemoid forms, occupying higher valued morphospace with regard to the latter. This supports Kociolek and Stoermer's ${ }^{11,13}$ hypotheses about the phylogenetic position of Reimeria ${ }^{9}$ in contrast to Krammer and Lange-Bertalot's ${ }^{23}$ and Cox's ${ }^{24}$ hypotheses of Reimeria's close affinity to gomphonemoid taxa.

Encyonema occupied lower valued morphospace with respect to cymbelloid taxa and higher valued morphospace with respect to Anomoeoneis, Placoneis and Brebissonia. Overall, with the exception of its position with respect to Reimeria, Encyonema occupied lower valued morphospace with respect to cymbelloid forms, not gomphonemoid forms, regardless of its position within theoretical morphospace. This supports Kociolek and Stoermer's ${ }^{11,13}$ hypotheses that Encyonema is a primitive cymbelloid form, and the same result was found in the previous study of theoretical morphospace. ${ }^{7}$

Gomphonemoid and gomphocymbelloid forms occupied higher valued morphospace compared to cymbelloid forms, with gomphocymbelloid occupying the highest valued morphospace of the three types of forms. Overall, gomphocymbelloid morphospace was distinct and was the highest valued morphospace with the exception of Didymosphenia. This is somewhat similar to that hypothesized by Kociolek and Stoermer ${ }^{11^{-13}}$ in their cladistic analysis, but the position of all gomphonemoid forms remains unresolved, including Gomphoneis ${ }^{11,12}$ and Gomphocymbella. ${ }^{11,14}$ Gomphonema is a non-monophyletic genus of clavate-formed diatoms that cannot be phylogenetically resolved using only theoretical morphospace analysis of form. Perhaps a form-based theoretical morphospace including other morphological characters used to refine and redefine the morphospace would be helpful; however, such an analysis has yet to be devised.

The highest valued morphospace belonged to Didymosphenia, since it was the most different in the $z$-direction from naviculoid, cymbelloid and gomphonemoid forms. In the $x$ - and $y$-directions, Didymosphenia occupied the same high valued morphospace as cymbelloid forms, which was lower valued combined morphospace compared to the combined morphospace for Didymosphenia, gomphonemoid and gomphocymbelloid forms. That is, Didymosphenia is more closely associated with cymbelloid forms rather than gomphonemoid forms (Fig. 5). This mostly supports 
the findings of Kociolek and Stoermer's ${ }^{11}$ cladistic analysis that Didymosphenia is more closely related to Cymbella mexicana in particular, and therefore cymbelloid taxa, not gomphonemoid taxa.

\subsection{Theoretical morphospace and other applications}

In their cladistic analysis, Kociolek and Stoermer ${ }^{11,13}$ used asymmetry about the apical, transapical and pervalvar axes as one of the multistate coded morphological characters. Differences in surfaces generated by 3D parametric equations of gomphonemoid and cymbelloid diatom forms are geometric indicators of axial asymmetries $^{7}$ and may be construed as proxies for the morphological character of asymmetry. However, there is some controversy surrounding the issue of importance of symmetry in diatom taxonomic and systematics studies. ${ }^{11,21,25}$

By minimizing the differences between variables from form to form, most of the differences between forms are produced in the $x$ - and $y$-directions, since the $z$-direction equals zero except in the case of Didymosphenia (Table 1). The difference between gomphonemoid and cymbelloid forms may be generalized as: the more clavate forms change by a parameterized hyperbolic secant function in the $x$-direction; the more crescentic forms change by a parameterized hyperbolic secant in the $y$-direction.

A comparison of all theoretical forms without consideration for size can illustrate the generalized change in form in the $x$ - and $y$-directions. By lining up representative forms generated by $3 \mathrm{D}$ parametric equations so that the apical axis is parallel to the $x$-direction in all cases, and superimposing a sine wave on each form so that the maximum amplitude is at the halfway point transapically, gomphonemoid forms are "out of phase" with Didymosphenia, cymbelloid and naviculoid forms (Fig. 7). Geometrically, this may show how theoretical morphospace analysis supports Kociolek and Stoermer's ${ }^{11,13}$ contention that, in this case, transapical asymmetry is not important with respect to Didymosphenia since the taxon is hypothesized to be more closely related to cymbelloid forms.

Size, geometry and shape of naviculoid, cymbelloid and gomphonemoid taxa are characteristics of the morphological changes from one taxon group to another. However, size ranges of vegetative cells among the naviculoid, cymbelloid and gomphonemoid taxa are highly variable. ${ }^{23,26,27}$ Geometrically, these taxa, like all diatoms, are modifications of a flattened cylinder. Surface area to volume ratio among naviculoid, gomphonemoid and cymbelloid forms is also highly variable, ${ }^{7,28,29}$ so such ratios are of limited utility. Shape is the primary factor used in initial binning of taxa in classification schemes. ${ }^{22}$

Theoretical morphospace analysis as support for many of the provisions of Kociolek and Stoermer's ${ }^{11,13}$ phylogenetic hypotheses may be used to devise another framework to study the relationship between theoretical morphospace and evolution of forms. Theoretical forms rather than the differences in surfaces might be used in an approximate or quasi-adaptive walk. ${ }^{15}$ Within theoretical morphospace, 


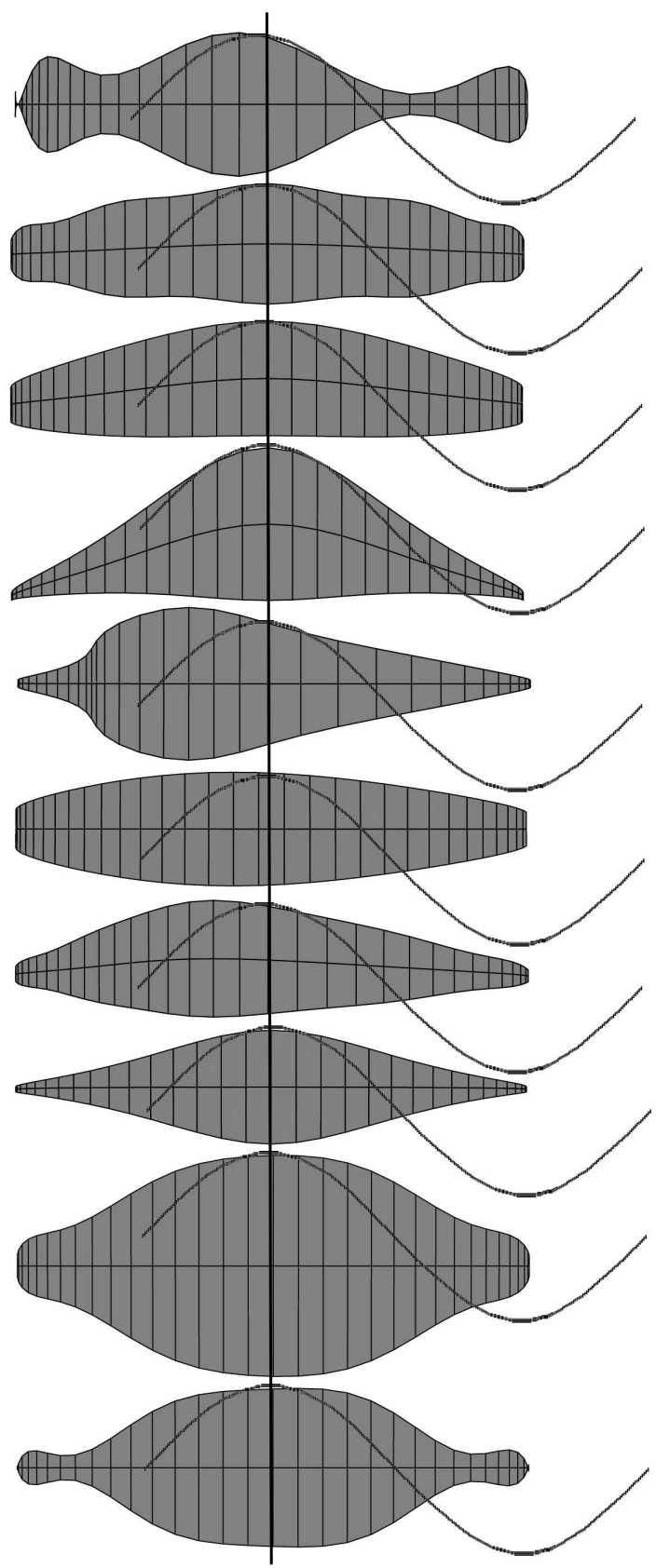

Fig. 7. Alignment of all forms and a sine wave superimposed on the forms in the apical-transapical plane. From top to bottom, Didymosphenia, Reimeria, cymbelloid, Encyonema, gomphonemoid, Gomphoneis, Gomphocymbella, Brebissonia, Placoneis, and Anomoeoneis. Gomphonemoid forms are approximately "out of phase" with naviculoid and cymbelloid forms and the Didymosphenia form. 


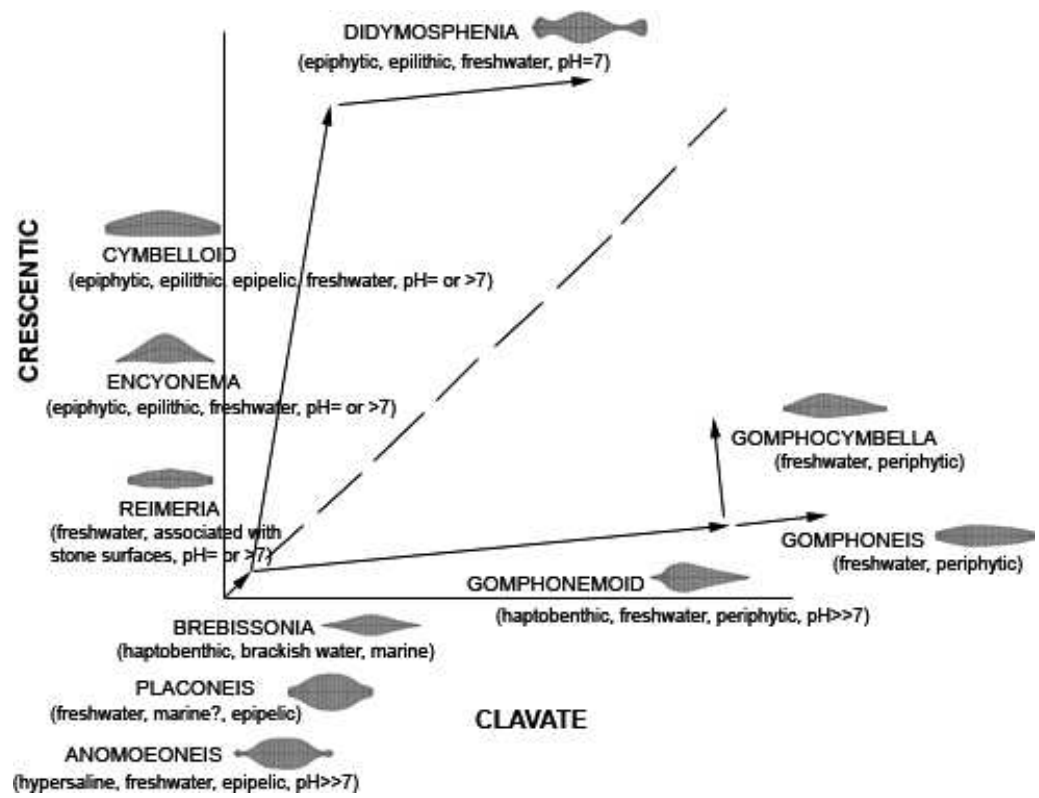

Fig. 8. Results from theoretical morphospace analysis and phylogenetic hypotheses for gomphonemoid and cymbelloid forms in an approximate adaptive walk. Information about habitat preferences and environmental tolerances are from Round et al. ${ }^{22}$ and Lowe. ${ }^{30}$

information about habitat preferences ${ }^{22}$ and environmental tolerances ${ }^{30}$ may be used as the adaptive features for each taxon group, and this is presented diagrammatically in Fig. 8. It is interesting to note that Didymosphenia is farthest removed in its preference for a freshwater, neutral habitat in contrast to gomphonemoid taxa (Fig. 8).

In terms of symmetry and shape, questions about the role of heteropolarity in diatom taxonomic and phylogenetic studies have been raised. ${ }^{11,21,25}$ Heteropolarity is considered to be an autapomorphic morphological character, and it has arisen many times and among many divergent phylogenetic groups. ${ }^{11,25}$ Valve asymmetry transapically and in the pervalvar plane, along with the morphological character of the apical pore field restricted to the smaller end of the valve, may occur as a single developmental or ontogenetic process in gomphonemoid diatoms. ${ }^{11,13,31}$

Does theoretical morphospace allow for inference about heteropolarity, and therefore indicate anything about ontogenetic pathways with respect to gomphonemoid (or possibly cymbelloid) taxa? That is, if results from theoretical morphological analysis indicate an implied degree of a characteristic such as heteropolarity, can ontogenetic trajectories, ${ }^{32}$ like a phylogenetic mapping, ${ }^{7,33}$ be implied in the theoretical morphospace?

Diatom ontogeny includes the process of size reduction during the asexual phase of the diatom life cycle. ${ }^{34-38}$ Rather than growth occurring as a diatom ages, daughter cells are made within the parent cell so that subsequent divisions 
produce species-specific offspring smaller than the parent cell. Sexual reproduction and auxosporulation induce size restoration, so size reduction as part of the diatom life cycle, may be an evolutionary mechanism that may have adaptive significance. ${ }^{39}$ In this study, size is not modeled so that inferring a relation between geometric results and the diatom vegetative life cycle is not possible. However, if size classes with respect to theoretical morphological variation within a form are congruent with a taxon at the species-level, this possibly could be incorporated into the total theoretical morphospace, then perhaps an approximate ontogeny may be inferred.

Perhaps, ontogenetic trajectories of gomphonemoid (and possibly cymbelloid) forms may be grossly inferred within theoretical morphospace, depending on how one describes the forms that make up that morphospace. In 3D parametric equations, developmental asymmetry may be represented by the removal of additional terms in the $y$-function of naviculoid forms to produce each cymbelloid form, and along with this, the addition of a term in the $x$-function to produce each gomphonemoid form (Table 1). For a gomphocymbelloid form, a Reimeria form with the addition of a term in the $x$-function would represent the combined asymmetry in the $x$ - and $y$-directions (Table 1 ). Speculatively, each theoretical form produced by $3 \mathrm{D}$ parametric equations may be the starting point of a vegetative stage of ontogeny, since the symmetry and shape of each form is approximately the most recognizable morphology for each taxon, namely, the morphology of a vegetative cell after formation of the post-auxospore initial cell. This is merely a vague conjecture that would require a much more detailed, directed analysis specifically geared toward studying diatom ontogeny with respect to size, symmetry and shape.

In order to make progress on the relationship between ontogenetic trajectories and theoretical morphospaces, more must be known about the diatom life cycle and the sequence of the formation of siliceous structures. Given the constraints imposed by the heritable property of approximate morphological fidelity during vegetative size reduction, ${ }^{40,41}$ and the ordered steps of silica deposition within a diatom cell, how one diatom form, such as a naviculoid one, might evolve into another diatom form, such as a gomphonemoid one, could be examined in a broader context with respect to theoretical morphospaces.

In general, the methods used here and in a previous study ${ }^{7}$ have been useful in evaluating inferences about phylogenetic hypotheses regarding gomphonemoidcymbelloid lineages. What do the results from this analysis imply for the testing of other diatom phylogenies? If forms can be modeled using 3D parametric equations for a group of closely related taxa, with a minimal difference between forms and parameters kept constant, it would be interesting to see if a given phylogenetic hypothesis may be supported and to what degree that support is evident. It would also be interesting to see if all forms in another phylogenetic grouping would exhibit a similar relation with regard to an approximate phase shift with respect to asymmetry. If they do, as in the case for gomphonemoid and cymbelloid forms, 
and additional groups of closely related taxon forms are tested producing similar results, a general test could possibly be developed to match phylogenetic outcomes to theoretical morphospace.

\section{Acknowledgment}

I would like to thank an anonymous reviewer for helpful suggestions that improved the manuscript.

\section{References}

1. McGhee Jr GR, Theoretical Morphology: The Concept and Its Applications, Columbia University Press, New York, 1999.

2. Tyszka J, Morphospace of foraminiferal shells: results from the moving reference model, Lethaia 39:1-12, 2006.

3. Raup DM, McGhee Jr GR, McKinney FK, Source code for theoretical morphologic simulation of helical colony form in the bryozoa, Palaeontol Electronica 9:1-16, 2006.

4. McGhee Jr GR, The Geometry of Evolution: Adaptive Landscapes and Theoretical Morphospaces, Cambridge University Press, Cambridge, 2006.

5. Pappas JL, Geometry and topology of diatom shape and surface morphogenesis for use in applications of nanotechnology, J Nanosci Nanotechnol 5:120-130, 2005.

6. Sterrenburg FAS, Gordon R, Tiffany MA, Nagy S, Diatoms: living in a constructal environment, in Seckbach J (ed.), Algae and Cyanobacteria in Extreme Environments, Series: Cellular Origin, Life in Extreme Habitats and Astrobiology, Vol. 11, Springer, Berlin, pp. 141-172, 2007.

7. Pappas JL, Theoretical morphospace and its relation to freshwater gomphonemoidcymbelloid diatom (Bacillariophyta) lineages, J Biol Syst 13:385-398, 2005.

8. Kociolek JP, Stoermer EF, On the taxonomy and ultrastructure of the fossil diatom, Gomphoneis Cantalica, Cryptogam Algol 7:1-8, 1986.

9. Kociolek JP, Stoermer EF, A consideration of the ultrastructure of Cymbella sinuata and its allies, and their transfer to Reimeria, gen. nov., Syst Bot 12:451-459, 1987.

10. Kociolek JP, Stoermer EF, Geographic range and variability of the diatom (Bacillariophyceae) Gomphonema ventricosum Greg, Nova Hedwigia 45:223-236, 1987.

11. Kociolek JP, Stoermer EF, A preliminary investigation of the phylogenetic relationships among the freshwater, apical pore field-bearing cymbelloid and gomphonemoid diatoms (Bacillariophyceae), J Phycol 24:377-385, 1988.

12. Kociolek JP, Stoermer EF, Taxonomy and ultrastructure of some Gomphonema and Gomphoneis taxa from the upper Laurentian Great Lakes, Can J Bot 69:1557-1576, 1991.

13. Kociolek JP, Stoermer EF, Freshwater gomphonemoid diatom phylogeny: preliminary results, Hydrobiologia 269/270:31-38, 1993.

14. Kociolek JP, Stoermer EF, The diatom genus Gomphocymbella O. Müller: taxonomy, ultrastructure and phylogenetic relationships, Nova Hedwigia 106:71-92, 1993.

15. Niklas KJ, The Evolutionary Biology of Plants, University of Chicago Press, Chicago, 1997.

16. Schmid A-MM, III2, Morphogenetic forces in diatom cell wall formation, in BereiterHahn J, Anderson OR, Reif W-E (eds.), Cytomechanics, Springer, Berlin, pp. 183-199, 1987. 
17. Schmid A-MM, Aspects of morphogenesis and function of diatom cell walls with implications for taxonomy, Protoplasma 181:43-60, 1994.

18. Pickett-Heaps JD, Schmid A-MM, Edgar L, The cell biology of diatom valve formation, Prog Phycol Res 7:1-168, 1990.

19. Hamm CE, The evolution of advanced mechanical defences and potential technological applications of diatom shells, J Nanosci Nanotechnol 5:108-119, 2005.

20. Persistence of Vision Ray Tracer 3.6, POV-Ray Team (Persistence of Vision Raytracer Pty. Ltd., 2004), http://www.povray.org/.

21. Jones HM, Simpson GE, Stickle AJ, Mann DG, Life history and systematics of Petroneis (Bacillariophyta), with special reference to British waters, Eur J Phycol 40:61-97, 2005.

22. Round FE, Crawford RM, Mann DG, The Diatom: Biology and Morphology of the Genera, Cambridge University Press, Cambridge, 1990.

23. Krammer K, Lange-Bertalot H, Bacillariophyceae. 1. Teil: Naviculaceae, in Ettl H, Gerloff J, Heynig H, Mollenhauer D (eds.), Süßwasserflora von Mitteleuropa, Band 2/1, Gustav Fischer Verlag, Stuttgart, Jena, Germany, 1986.

24. Cox EJ, Taxonomy of diatoms: a fascination with minutiae, in Norton TA (ed.), Out of the Past. Collected Reviews to Celebrate the Jubilee of the British Phycological Society, The British Phycological Society, Belfast, pp. 49-67, 2003.

25. Williams DM, Cladistic analysis of some freshwater araphid diatoms (Bacillariophyta) with particular reference to Diatoma and Meridion, Plant Syst Evol 171:89-97, 1990.

26. Patrick R, Reimer CW, The Diatoms of the United States, Exclusive of Alaska and Hawaii, Vol. 1, The Academy of Natural Sciences of Philadelphia, Philadelphia, 1966.

27. Patrick R, Reimer CW, The Diatoms of the United States, Exclusive of Alaska and Hawaii, Vol. 2, The Academy of Natural Sciences of Philadelphia, Philadelphia, 1975.

28. Sicko-Goad LM, Schelske CL, Stoermer EF, A morphometric method for correcting phytoplankton cell volume estimates, Limnol Oceanogr 29:1170-1178, 1984.

29. Banse K, Cell volumes, maximal growth rates of unicellular algae and ciliates, and the role of ciliates in the marine pelagial, Limnol Oceanogr 27:1059-1071, 1982.

30. Lowe RL, Environmental Requirements and Pollution Tolerance of Freshwater Diatoms, EPA-670/4-74-005, National Environmental Research Center, Office of Research and Development, United States Environmental Protection Agency, Cincinnati, Ohio, 1974.

31. Hendey I, An introductory account of the smaller algae of British coastal waters. Part V: Bacillariophyceae (Diatoms), Fishery Investigations, Series IV, Her Majesty's Stationery Office, London, 317 pp., 45 pls, 1964.

32. Rasskin-Gutman D, Izpisúa-Belmonte JC, Theoretical morphology of developmental asymmetries, BioEssays 26:405-412, 2004.

33. Stone JR, Mapping cladograms into morphospaces, Acta Zool 84:63-68, 2003.

34. Pfitzer E, Über den bau and zellteilung der diatomeen, Bot $Z$ 27:774-776, 1869.

35. Pfitzer E, Untersuchungen über bau and entwicklung der Bacillariaceen (diatomeen), Bot Abh Geb Morphol Physiol 1:1-189, 1871.

36. MacDonald JD, On the structure of the diatomaceous frustule, and its genetic cycle, Ann Mag Nat Hist 4(3):1-8, 1869.

37. Edlund MB, Stoermer EF, Ecological, evolutionary, and systematic significance of diatom life histories, J Phycol 33:897-918, 1997.

38. Zurzolo C, Bowler C, Exploring bioinorganic pattern formation in diatoms. A story of polarized trafficking, Plant Physiol 127:1339-1345, 2001.

39. Lewis Jr WM, The diatom sex clock and its evolutionary significance, Am Nat 123: 73-80, 1984. 
40. Mann DG, An ontogenetic approach to diatom systematics, in Mann DG (ed.), Proceedings of the Seventh International Diatom Symposium, O. Koeltz, Koenigstein, pp. 113-141, 1984.

41. Mann DG, The origins of shape and form in diatoms: the interplay between morphogenetic studies and systematics, in Ingram DS, Hudson AJ (eds.), Shape and Form in Plants and Fungi, Academic Press, London, pp. 17-38, 1994. 